\title{
Entrepreneurs Entering The Higher Education Market To Make A Difference: The Kenney College Of Entrepreneurship
}

Matthew Kenney, (Email: mkenney@nova.edu), Kenney College of Entrepreneurship Bahaudin G. Mujtaba, (Email: mujtaba@nova.edu), Nova Southeastern University

\begin{abstract}
Higher education today is becoming more complex than ever and entrepreneurs are capitalizing on this market by making it more competitive and, hopefully, better. The Kenney College of Entrepreneurship, as one example, leverages the strengths of the established online operating systems in higher education, while implementing innovative strategies that will enhance studentprofessor interaction and student learning in a cyber environment. The key to the Kenney College of Entrepreneurship's strategy is appreciating the fact that entrepreneurs tend to learn differently than most other students and are interested in having some control in designing their learning outcomes. Therefore, this case discusses an innovative student-professor pedagogical model that is employed by the Kenney College of Entrepreneurship. The model strives to satisfy each student's internal locus of control and the college's desire to build a premium brand by emphasizing the humanistic, scholarly, and practical aspects of entrepreneurship. The case further discusses some of the challenges and opportunities facing educators and administrators.
\end{abstract}

\section{INTRODUCTION TO THE KENNEY COLLEGE OF ENTREPRENEURSHIP}

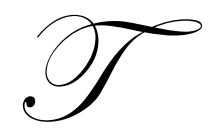

he Kenney College of Entrepreneurship is one of many institutions entering the competitive environment of higher education. The Kenney College of Entrepreneurship will be successful because it offers a different approach to teaching and, more specifically, developing entrepreneurs who can effectively compete in the twenty-first century's global marketplace or global market-space. The leaders at the Kenney College of Entrepreneurship realize that different is not necessarily better, but better is always different. As demonstrated in their mission statement, they are focused on offering both a better and different model to learning in higher education:

The mission of Kenney College of Entrepreneurship is to become the premier accredited provider of online undergraduate entrepreneurship education in the United States. We will facilitate a paradigm shift in online education by allowing students to take an active role in the design and delivery of curriculum by working with professors to tailor courses and outcomes to their unique learning styles and professional backgrounds. All stakeholders will benefit from an environment that explores entrepreneurship from scholarly, practitioner, and humanistic perspectives.

Kenney College of Entrepreneurship will be competing within the $\$ 230$ billion for-profit segment of the US higher education industry (Lechuga, 2006). While academia is a mature industry, the for-profit segment is in the rapid growth stage of the life cycle, as the amount of two year and four year for-profit colleges within academia has grown $78 \%$ and $266 \%$ respectively since 1998. 


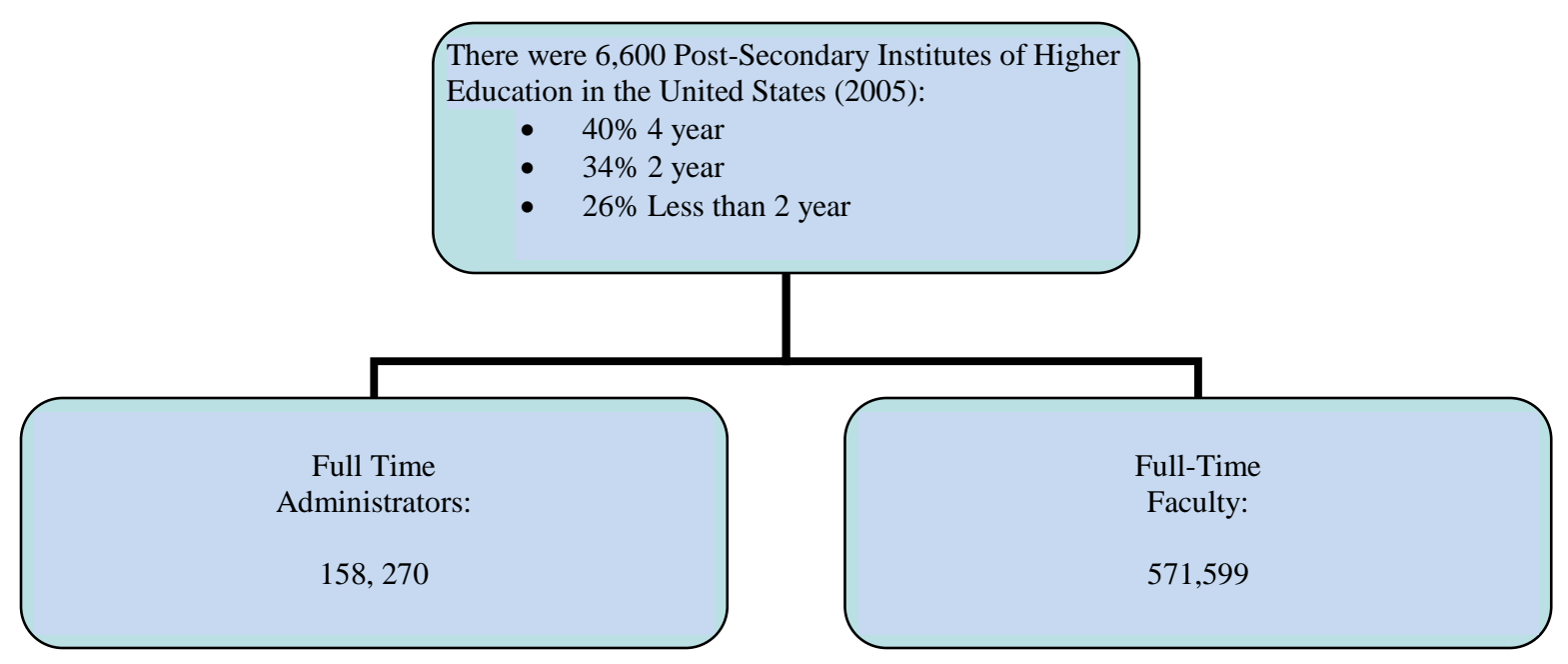

Figure 1: Adapted from NCES (2006) and Back Issues in Higher Education Journal (2004)

While there has been debate within the academic community relative to the quality of online delivery and whether it is helpful or harmful to the future of higher education (Berg, 2005), student achievement levels within an online environment are consistent with that of traditional courses (Katz \& Yablon, 2003). Moreover, online classes are increasingly preferred by students as they are viewed as being academically rigorous, yet much more convenient (Pope, 2006).

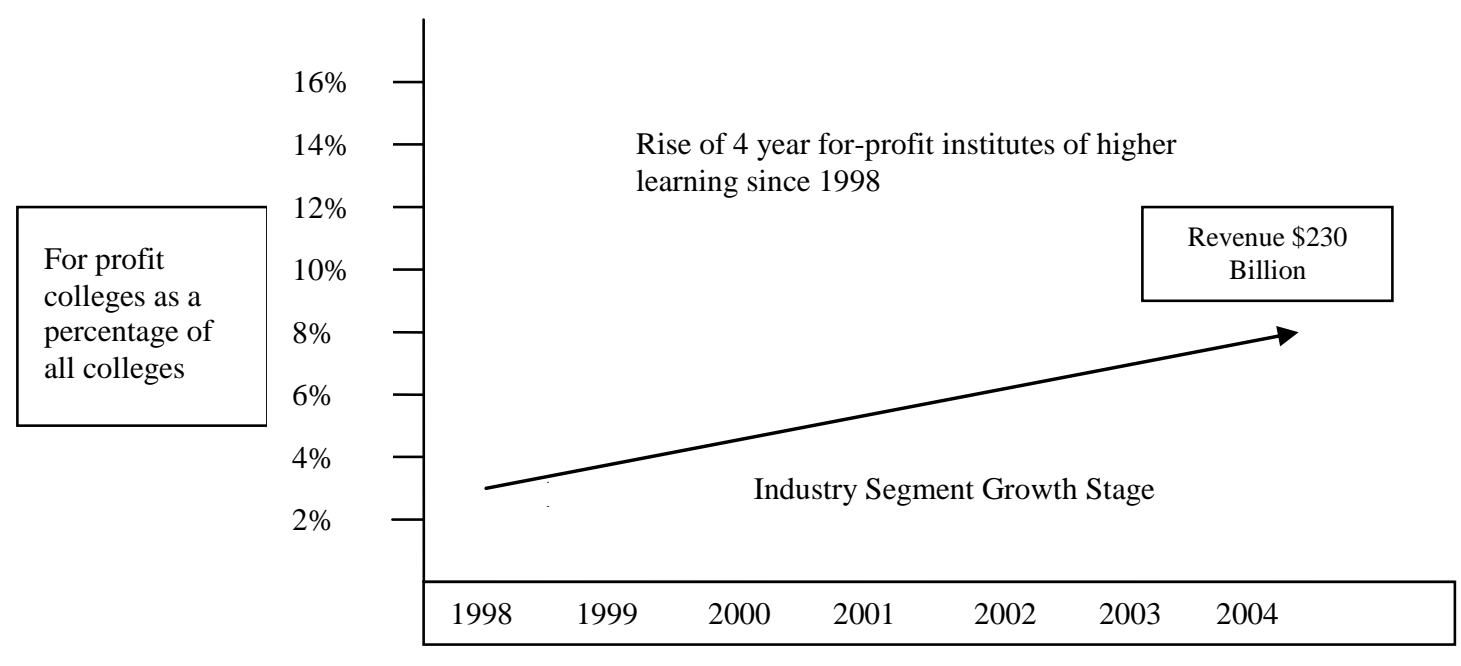

Figure 2: Rise in For-Profit Institutes (adapted from Lechuga, 2006)

\section{ASSESSMENT OF STUDENT LEARNING}

The assessment of learning, in both online and onground modalities, is important from many perspectives. The most fundamental outcome is to help dedicated faculty strive for personal improvement in delivering meaningful courses to students. An effective evaluation can suggest where teaching strategies are being successful and where new strategies might be needed. Assessment is also central to providing institutional accountability for each program offered by a school. Various reports from accrediting agencies have proposed assessment as a productive mechanism for responding to the concerns of students, parents, accrediting bodies, and government agencies. Finally, assessment 
is a key focus of governmental and accrediting agencies that are charged with assuring quality education. Without timely and accurate information, reasoned judgments are nearly impossible in developing policies that will lead to continuous improvement in the delivery of education (Moore, 2003).

Outcomes assessment is of particular concern to faculty, institutions, and regulating agencies when students use distinctively different learning modalities to achieve their educational goals. Online instruction is clearly one of the more controversial of these modalities. As Ryan (2002) observes, "It is almost assured that, as more classes are offered online and become interchangeable at different universities, the proliferation of use by students will increase because of the "anywhere, anytime nature" of the Internet." Consequently, a heightened effort is underway to examine the educational outcomes of students that are completing all or part of their coursework online versus those students that are completing their education entirely through traditional campus-based courses. This information is critical to determining if online classes are "next best thing" to attending traditional lecture classes or if online and traditional modes of instruction are essentially equivalent in the quality and comparability of the learning experience.

The importance of demonstrating the quality of electronically offered degrees and certificate programs is now an important component of regional accrediting agencies. Much of their concern is directed toward the many new providers of education that rely on electronic instruction for the delivery of academic services. A Statement of Commitment (NCACIHE, 2004) issued by the regional accrediting commissions recognizes the innovations made by these new programs. However, these often highly innovative delivery systems raise fresh questions regarding the nature and content of an educational experience and the resources required to support them. The concerns of the eight accrediting commissions are aimed at ensuring the quality of service delivery in distance education. To ensure quality, the commissions have agreed upon a set of Best Practices that colleges and universities should follow in offering electronically provided degree and certificate programs. A key component of these best practices is Evaluation and Assessment:

Both the assessment of student achievement and evaluation of the overall program take on added importance as new techniques evolve. For example, in asynchronous programs the element of seat time is essentially removed from the equation. For these reasons, the institution conducts sustained, evidence-based and participatory inquiry as to whether distance learning programs are achieving (their) objectives. The results of such inquiry are used to guide curriculum design and delivery, pedagogy, and educational processes, and may affect future policy and budgets and perhaps have implications for the institution's roles and mission (SACS, 2004).

Many higher education institutions have responded to this outcomes assessment challenge by completing studies designed to compare the performance of students in courses conducted in online and through traditional teaching modalities. For example, an initial study by Nova Southeastern University researchers sought to evaluate the effectiveness of online versus traditional in-class instruction was conducted by Schulman and Sims (1999). Schulman and Sims' research population consisted of students enrolled in five different undergraduate courses in a variety of undergraduate disciplines where the online and onground sections were being taught by the same instructor. Students received a pretest and a posttest on the subject matter of the course that was developed by the course instructor. The students received a posttest at the end of the course that was again designed by the instructor. The results revealed that, while the online students scored significantly higher than the in-class students on the pretest, no statistically significant difference was observed in the posttest scores for the two groups. Schulman and Sims conclude that differences in the pretest scores may be the result of better prepared students self selecting themselves into the online sections. They note, nevertheless, that preparation in itself does not lead to greater learning based on the mode of instructional delivery given the similar outcomes in the posttest scores. The NSU Office of University Research and Planning followed with a series of studies that were designed to compare student performance in courses conducted in both online and traditional formats. The results were mixed in that undergraduates appeared to do better in traditional classroom situations while graduate students outperformed their traditionally based counterparts (Fredda, 2000d). This outcome led to subsequent studies that tried different research strategies. One approach sought to link outcomes to specific undergraduate and graduate research centers. The results of these studies continued to show that undergraduate students in traditional classroom settings performed better than online studies (Fredda, 2000a). The graduate school studies found either no statistically significant difference in the instructional modality (Fredda, 2000c) or online-based students performing better than their classroom peers (Fredda, 2000b). A second approach sought to control for the possible effects of different instructors, syllabi, texts, assignments, and examinations between online and traditional classroom sections of the same course. To achieve these statistical controls, research 
focused on a single course taught in both formats by the same instructor using the same text, assignments, and examinations. Using the mid-term examination scores, the study found no statistically significant difference in student performance between a weekend course taught off-campus and the same course taught through electronically-mediated instruction (Moorhouse, 2001). A follow-up study that compared final examination scores of students receiving face-to-face instruction in Nassau, Bahamas, and online students again found no statistically significant differences in course outcomes despite the differing instructional modalities (Moorhouse \& Mujtaba, 2004).

At the Kenney College of Entrepreneurship, assessment of learning will take place on a regular basis by faculty members and administrators for continuous improvement purposes. The results of such studies will be shared with all faculty members and administrators to discover best modes of teaching online students and further enhancing the learning environment for everyone. Since the Kenney College of Entrepreneurship will be using updated cyberspace technologies with an innovative model tailored specifically toward entrepreneurs, faculty training and development will be an integral part of the program.

\section{A DIFFERENT MODEL: EDUCATION TAILORED TO ENTREPRENEURS}

According to Terenzio (2002) there has always been "a special mission entrusted to higher education to foster human development and democratic values" (p. 29), and Kenney College will stay true to this mission. However, it is important to note that academia consists of two very different paradigms: the non-profit sector and the for-profit sector.

The non-profit segment of academe culture reflects a hybrid of the British and German traditions (Bergquist, 1992), whereby research and scholarly pursuits are emphasized over teaching and service, thus leaving critics to question the relevance of a college degree in the competitive $21^{\text {st }}$ century marketplace. By contrast, the forprofit segment relies primarily on adjunct professors who emphasis practicality over theory (Lechuga, 2006); demonstrates a corporate mentality, and place less emphasis on encouraging academic freedom among their professorate (Rice, 2002), giving rise to what Ritzer (2002) calls The McDonaldization of the academy.

Online education has, however, become a vital component of both the for-profit and non profit sectors. According to the Sloan Consortium (2006):

- $62 \%$ of academic leaders rated online learning as equal to or superior to face-to-face classes.

- In 2005, about 3.2 million college students took online classes representing an 800,000 student increase from 2004.

- $\quad 63 \%$ of traditional schools offer online classes and/or degree programs.

- $\quad 53 \%$ of college leaders cited online courses as a critical element of their long-term strategy.

- $\quad$ Online students are primarily undergraduates.

The Kenney College management team maintains that high scholarly standards and for-profit status are not mutually exclusive objectives. The path to developing a quality program and enhancing profitability lies in fostering a productive student-professor relationship that appreciates the fact that each student has a different learning style (Whitely, 2007). Therefore, Kenney College students will work with their professors to tailor course material around their particular learning style.

\section{PROFESSOR - STUDENT COLLABORATION: VAK MODEL}

people:

Smilor (2006) notes that entrepreneurs tend to be exceptional learners, but learn differently than most

Learning must be action oriented and practical. Analysis is fine, but take-aways from the learning process must be translated into immediate solutions to problems or means to take advantage of upcoming opportunities. Learning must involve and engage entrepreneurs. That is, it must in some way be customized to address their issues, 
challenges and needs. It is in this sense highly experiential. Entrepreneurs thus learn from everyday interactions with customers, suppliers, and competitors or they learn in more formal programs through experiential exercises, case studies or hands-on spreadsheets (p. 1).

Our value proposition and source of strategic competitive advantage is the acknowledgement, and appreciation, of the fact that entrepreneurs learn differently than most people. The traditional pedagogical approach used in academia is not complimentary to the learning preferences of entrepreneurs, who tend to be experiential learners. Therefore, while Kenney College professors will have the academic freedom to design challenging courses with measurable outcomes, course case studies may be tailored to a student's prospective career path and/or the industry he/she plans on pursuing. This will empower students and satisfy their internal locus of control, which tends to be highly developed in entrepreneurs (Hofstrand, 2006). For example, a student working on a marketing case study could, in partnership with his/her professor, could tailor the case to reflect his/her preferred industry. Thus, all of the research gleaned will have a practical application.

Whiteley (2007) notes that it is projected that 1 in 10 college students will be an online student by 2008, yet online modules are not tailored to meet the needs of varied learning styles (Whiteley 2007). Upon admission into Kenney College students will take a VAK test to identify if their learning style is visual, auditory, or kinesthetic (Clark, 2000). Professors will be aware of their students' learning style and modify assignments to those styles. This approach will require the professor to be engaged fully in the student's development.

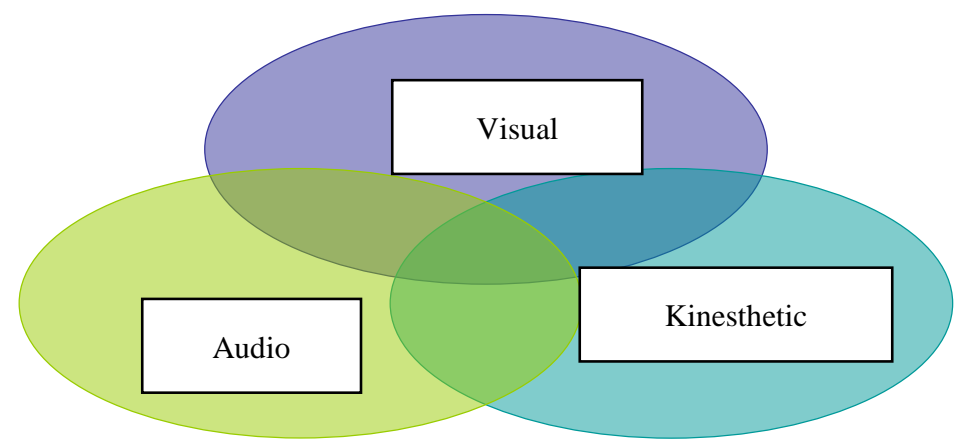

Figure 3: VAK Learning style test. Adapted from Whiteley (2007)

It is important to note, however, that while efforts will be made to accommodate each student's learning style, students will be exposed to various learning methodologies to provide them with a broader collegiate experience. According to Zapalska and Broznik (2006):

Online learning can be improved by providing instruction in a manner consistent with each student's learning style. However, it is important to keep in mind that, even if a specific student learns best in a certain way, he or she should be exposed to a variety of learning experiences to become a more versatile online learner.

The model employed by our competitors is essentially the traditional instructional model implemented in a virtual environment. No effort is made to tailor content to student learning styles. A comparison of traditional online methodologies to the Kenney Model is presented in Table 1. 
Table 1: Comparison of Traditional Online Methodologies to the Kenney Model

\begin{tabular}{|c|c|c|}
\hline Traditional online pedagogical model & Vs. & Kenney Online Model \\
\hline $30: 1$ Student/faculty ratio & Vs. & 15:1 Student/faculty ratio. \\
\hline Group projects mandatory & $\begin{array}{c}\text { No group projects. Informal Student interaction } \\
\text { encouraged. }\end{array}$ \\
\hline $\begin{array}{c}\text { Standard curriculum used by all students in a } \\
\text { class. }\end{array}$ & Vs. & $\begin{array}{c}\text { Flexible curriculum tailored to the unique learning style } \\
\text { of the student. }\end{array}$ \\
\hline Adjunct professors & Vs. & Full-time professors \\
\hline Focus on practical, vocational training. & Vs. & $\begin{array}{c}\text { Focus on scholarship, the humanities, and practicality. } \\
\text { Academically rigorous. }\end{array}$ \\
\hline Asynchronous delivery. Five to Six week Module & Vs. & Asynchronous delivery. Six-week Flex-module. \\
\hline
\end{tabular}

A key feature of the Kenney College model is that all of our instructors will have a combination of entrepreneurial experience and scholarly credentials. It is the contention of our management team that students need a strong foundation in entrepreneurship and business theory to succeed in practice.

\section{FACULTY-STUDENT INTERACTION}

Using Camtasia audio software, professors will record voice over PowerPoint presentations, discussing each individual assignment, as well as base and advanced theory in the subject area. Presentations will be archived for easy $24 / 7$ access. Students will also have access to a class discussion board, which will serve as an information, communication, and research portal. Instructor feedback will be confidentially placed in an online grade book, similar to those used by other online colleges.

Rolling admission will be employed, thus each student will coordinate due dates and deliverables with his/her instructor. Kenney College of Entrepreneurship will implement a six week flex-module, whereby students have more flexibility in the delivery of assignments. For example, if the student feels she can complete the given assignments in five weeks she may do so. Student-faculty interaction at Kenney College is similar to that found in a traditional independent study.

\section{THE ENTREPRENEUR AS STUDENT}

Entrepreneurs tend to be motivated by achievement, rather than affiliation (McClelland, 1961); value flexibility and are self motivated (Kenney \& Mujtaba, 2007). These same traits are hallmarks of the successful online student. Moreover, successful online and for-profit students tend to be older than traditional students (Antonucci, 2001) and more comfortable with untraditional learning environments (Lechuga, 2006), which also compliments our business model. Kenney College students are not likely to be motivated by affiliation and presumably working full-time (or possibly on a start-up venture) therefore group projects will not be utilized as a learning methodology. However, students will be encouraged to participate on asynchronous discussion board to give advice and receive feedback to their classmates.

\section{OPERATING SYSTEM}

Academia is a unique industry (Rhodes, 2002; Fisher \& Koch, 2004; Shane, 2004) in that it is not truly a service. However, although operating philosophies differ between non-profit and for-profit academic organizations, the operating system used by academic institutions is well established and successful. Thus, Kenney College will employ the same operational paradigm, as presented in Figure 5. 


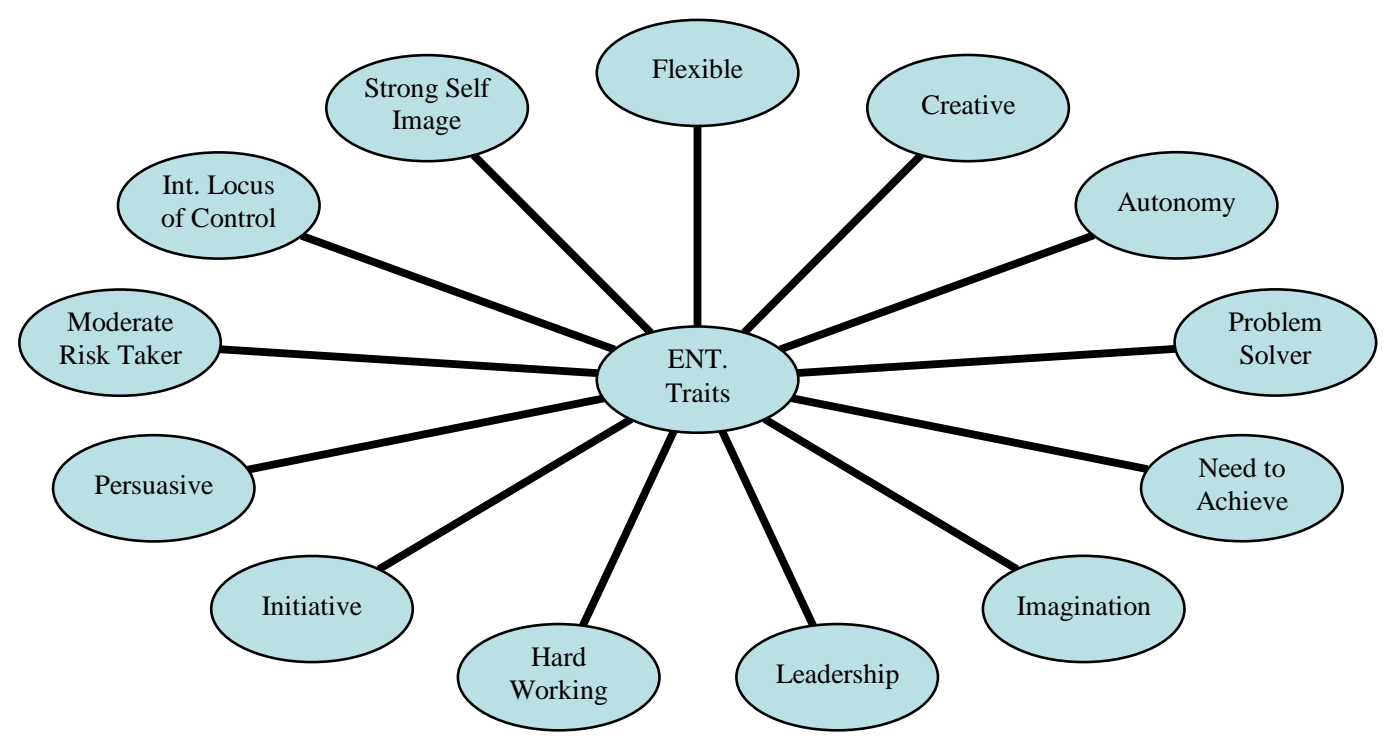

Figure 4: Entrepreneurial Traits image adapted from Kenney \& Mujtaba (2007)

\section{STRATEGIC PRIORITIES}

Cost, delivery, flexibility and quality have been identified as key operational priorities.

Quality. A fundamental mistake made by most online service providers is that they do not tailor their marketing plan around their operational realities (Boyer, Tomas \& Hult, 2005), therefore our strategy is conservative and heavily influenced by our operational abilities. Kenney College is servicing a niche segment and is uniquely positioned to develop a premium brand. And, justifiably, demand a premium price for its service. The company's value proposition leverages its full-time faculty, independent study model, and advanced technological resources and student involvement in the design of their curriculum delivery.

Delivery. Kenney College of Entrepreneurship will operate entirely as an online entity. Students will have $24 / 7$ access to course materials and resources, and develop individual learning plans with their instructors to assure their preferred learning style is engaged. Professors will provide detailed feedback and provide students with a detailed rubric to illustrate areas that need improvement.

Flexibility. Students will essentially have five weeks worth of assignments distributed over a six-week period. This flex-module is especially designed for entrepreneurial personalities who have a strong locus of control. Since entrepreneurs are more likely to have learning disabilities (Stanley, 2000) various workshops will be conducted to assist learning disabled students with their particular area of difficulty.

\section{OPERATIONAL TASKS}

Curriculum design. A pressing operational challenge is developing an online curriculum that is academically rigorous and student centered (Rudestam \& Schoenholtz-Read, 2002), but flexible enough to be modified to the student's research interest and learning style. Kenney College will offer a 120 credit hour Bachelors of Science in Entrepreneurship degree. Courses will be offered in sequential six week flex-module terms and be drawn from six academic disciplines: marketing, management, quantitative studies, communications, humanities, and entrepreneurship: Students will be required to complete two courses per term, and thirty 4-credit courses in total. There will be a one week break between terms, thus full-time students should complete their degree in 102 weeks, or about two years. 


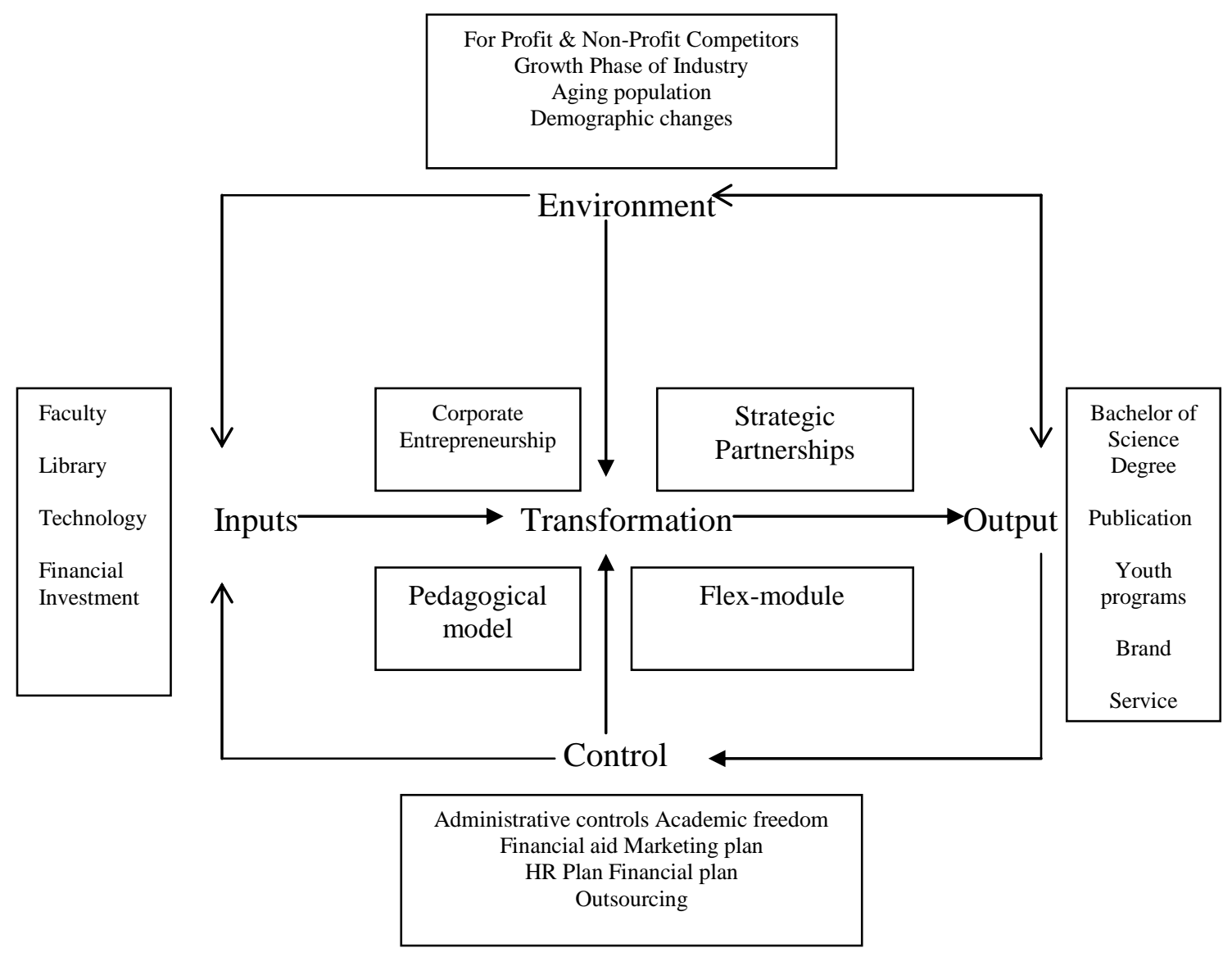

Figure 5: Operating Systems and the Environment (Adapted from Lawrence, 2007)

\section{Quality}

- Independent Study

$-24 / 7$

- Rich media

- Pod-casting

- Mobile integration

- Full-time faculty

- Flex-module

- Learning disability

resources

- Rolling admissions

- Curriculum modification

Delivery

- Peer-to-Peer Networking

- Asynchronous delivery

- Financial aid

- Military programs

- Scholarships

Cost

Figure 6: Cost, delivery, flexibility and quality model (Adapted from Lawrence, 2007) 
Table 2: Course and Subject Matter

\begin{tabular}{|c|c|c|c|c|c|}
\hline Marketing & Management & $\begin{array}{c}\text { Quantitative } \\
\text { Studies }\end{array}$ & Communications & Humanities & Entrepreneurship \\
\hline $\begin{array}{l}\text { Introduction to } \\
\text { Marketing }\end{array}$ & $\begin{array}{c}\text { Introduction to } \\
\text { Management }\end{array}$ & $\begin{array}{l}\text { Accounting for } \\
\text { Entrepreneurs }\end{array}$ & $\begin{array}{l}\text { Introduction to } \\
\text { Communications }\end{array}$ & $\begin{array}{l}\text { Logic } \\
\text { Ethics }\end{array}$ & $\begin{array}{l}\text { Opportunity } \\
\text { Research }\end{array}$ \\
\hline E-business & $\begin{array}{l}\text { Human } \\
\text { Resource }\end{array}$ & $\begin{array}{l}\text { Personal } \\
\text { Finance }\end{array}$ & Business Writing & Psychology & $\begin{array}{l}\text { The } \\
\text { Entrepreneurial }\end{array}$ \\
\hline $\begin{array}{l}\text { Advertising \& } \\
\text { Promotions }\end{array}$ & Management & Capital Markets & $\begin{array}{c}\text { Business } \\
\text { Presentations }\end{array}$ & Sociology & Mind \\
\hline Branding \& & $\begin{array}{l}\text { Family } \\
\text { Business }\end{array}$ & and Forecasting & Emotional & History of & Intrapreneurship \\
\hline $\begin{array}{l}\text { Positioning } \\
\text { Operations }\end{array}$ & Leadership & $\begin{array}{l}\text { Creative } \\
\text { Financing } \\
\text { Methods }\end{array}$ & $\begin{array}{c}\text { Intelligence } \\
\text { Virtual }\end{array}$ & Entrepreneurship & $\begin{array}{c}\text { Feasibility } \\
\text { Analysis }\end{array}$ \\
\hline Management & $\begin{array}{l}\text { Information } \\
\text { systems }\end{array}$ & $\begin{array}{l}\text { Debt and } \\
\text { Private Equity } \\
\text { Financing }\end{array}$ & Communications & $\begin{array}{c}\text { * Each class is } 4 \\
\text { credit hours. }\end{array}$ & The Business Plan \\
\hline
\end{tabular}

Technology. The technological infrastructure for Kenney College will build upon a platform provided and supported by a leading e-learning software company (i.e. Blackboard, ecollege etc.). Students will receive:

- $\quad 24 / 7$ access to several dozen multi-media presentations

- $\quad$ Links to discussion boards

- $\quad$ Access to a comprehensive library and e-books

- $\quad$ Access to a virtual commons, where special interest and study groups will meet

Operational plan. Kenney College will develop internal admissions and lead management processes. Additionally, academic record management software will be utilized to track student development and maintain academic transcripts. To assure security and mitigate risk, records will be backed-up daily and a copy will be stored off-site in a data warehouse. General administrative functions, such as payroll, will be outsourced. However, the college will develop relationships with the following professional service providers:

- $\quad$ Financial Management - Kenney College management has begun negotiations with several private student loan companies to provide student financial aid processing and billing services. Leveraging the core competencies of an industry leader in this field will result in consumer confidence and decreased risk (Lincoln, 2001). Kenney College will not be eligible to participate in Federal student loan programs until accreditation has been achieved.

- $\quad$ Online Library - By participating in the Solinet Consortium, a non-profit network of public and academic libraries, Kenney College will be able to provide access to top flight academic databases including: ABI Inform, Lexis-Nexis, Wilson, and Emerald Management Extra. According to Solinet (2007) membership in the consortium includes:

- Full access to online databases and inter library loan programs

- One time fee: $\$ 500$

- Annual Fee: $\$ 660$

- $\quad$ Accreditation - Kenney College will seek accreditation through the Distance Education and Training Council (DETC). DETC was established in 1926 and is recognized by the US Department of Education and The Council for Higher Education Accreditation (DETC, 2007). Members may participate in Federal student aid; Pell Grant; and GI Bill funding programs. In order to attain accreditation Kenney College must: - Demonstrate two consecutive years of operation.

- Demonstrate that students have successfully completed the stated curriculum.

- Submit two-years of audited financial statements for Department of Education review and approval. 


\section{MARKETING PLAN}

Market orientation. Kenney College is especially well positioned for long-term viability; scalability; and profitability as it possess two of the key components researchers have identified as antecedents of organizational success: entrepreneurial orientation and market orientation (Barrett \& Weinstein, 1998; Matsuno, Metzker \& Ozsomer, 2002).

Keys to being market oriented are: maintaining a keen awareness of the firm's environment; understanding and anticipating needs of your prospects and customers; and developing innovative services that generate a first mover advantage.

\section{ENVIRONMENTAL FORCES}

The following SWOT and PEST analyses provide an overview of the internal and external environment:

Strengths. Kenney College's founder and first full-time faculty member, Kenneth Proudfoot, have both won awards and accolade for their innovative teaching methodologies (Franklin University, 2005; Freedoms Foundation, 2006). Moreover, both have significant start-up experience and prior entrepreneurial success.

Another key strength is the low faculty to student ratio and unique independent study-like pedagogic model, which emphasize flexibility without a corresponding decrease in quality. The productivity ratio of faculty members will be capped at 1-to-15, and will likely be considerably lower in the first year of operation, which should create a significant value added benefit for students.

Weaknesses. Kenney College has weaknesses similar to those of many start-up ventures, including the possibility of being undercapitalized and being unable to attract top flight job prospects. Risks will be identified, analyzed, and treated as part of the company's comprehensive risk management plan (Cooper, Grey, Raymond, \& Walker, 2005). Undercapitalization poses risk at both the strategic and functional levels of the operation, however, we believe much of the risk can be mitigated by outsourcing administrative processes that lay outside the core competencies of the management team and/or staff.

The inability to become accredited until two years of continuous operations has been achieved is a significant weakness for Kenney College, which is very difficult to mitigate. However, by implementing the operational controls (i.e. administrative support, financial aid) accrediting bodies seek (Coffee \& Millsaps, 2004) throughout the nascent stages of the venture the firm should be well positioned in two years to attain accreditation.

Opportunities. The for-profit segment of higher education is in the growth phase of the product life cycle (Lechuga, 2006), and Kenney College is poised to be the first online for-profit college in the United States to offer a bachelor of science in entrepreneurship degree. Moreover, our unique pedagogic approach and ambitious public relations initiatives will position us as a lucrative niche player in the industry, and ideally an attractive M\&A target within the next decade.

Threats. The for-profit sector of high education is dominated by two public companies: Apollo Group and Career Education Corporation. The Apollo Group operates University of Phoenix and several other schools with combined enrollment of over three hundred thousand students (Kamenetz, 2005). Apollo generated 2005 gross revenue of \$2.53 billion and an EBITDA of \$783 million (Yahoo Finance, 2007). Career Education Corporation, which owns over eighty colleges and serves over ninety thousand students (CEC, 2007) generated 2005 gross revenue of $\$ 1.79$ billon with an EBITDA of $\$ 332.19$ million. While it is unlikely that either of these entrenched players will replicate the Kenney College pedagogic model, it is possible that they, or another competitor, could launch an online entrepreneurship college. The only real barrier to entry would be developing a faculty base qualified to teach entrepreneurship. 


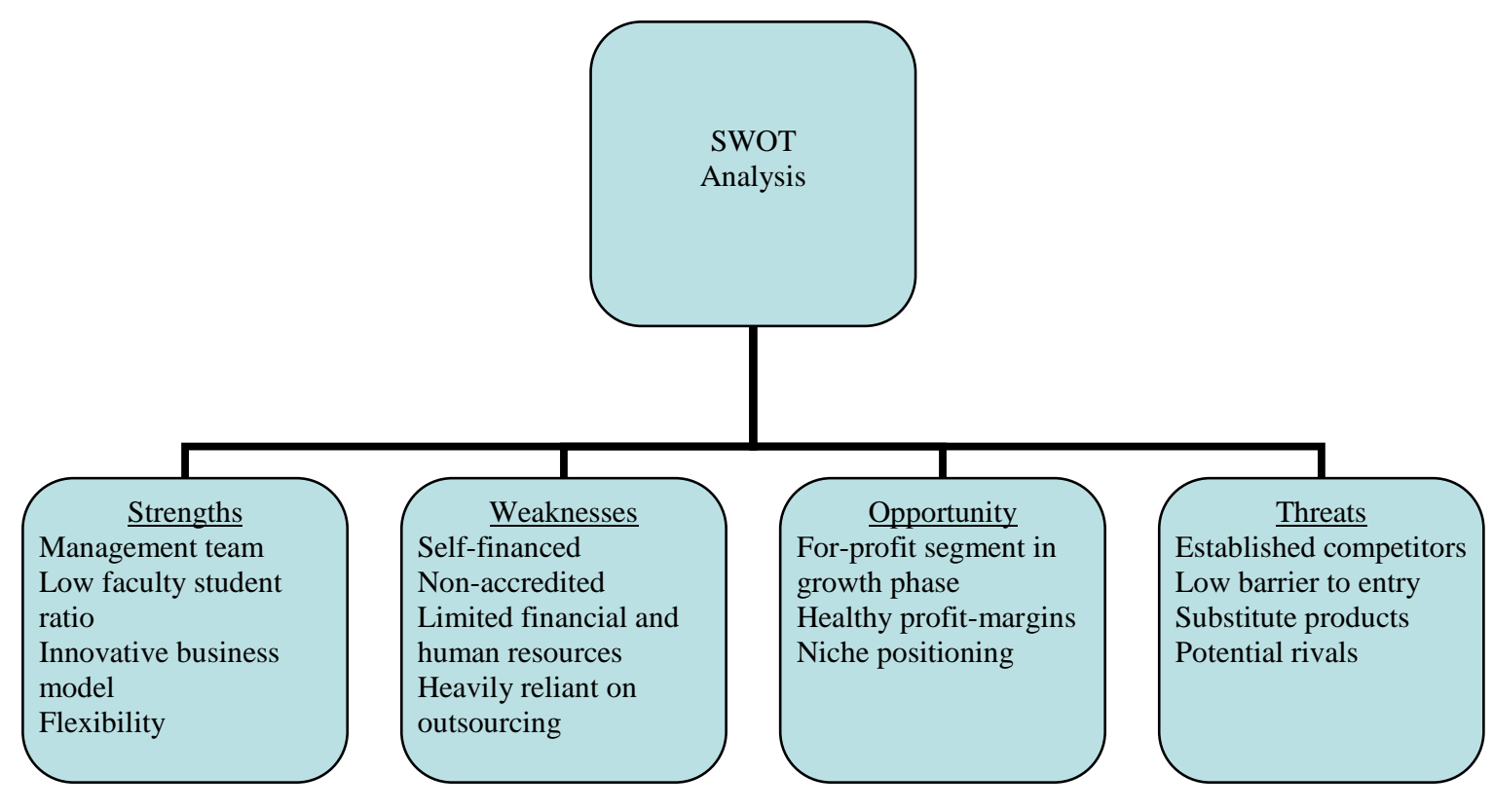

Figure 7: SWOT Analysis

\section{PEST ANALYSIS}

The synopsis, presented in Figure 8, identifies political, economic, societal and technological factors within the external environment which may positively, or negatively, affect the company's future.

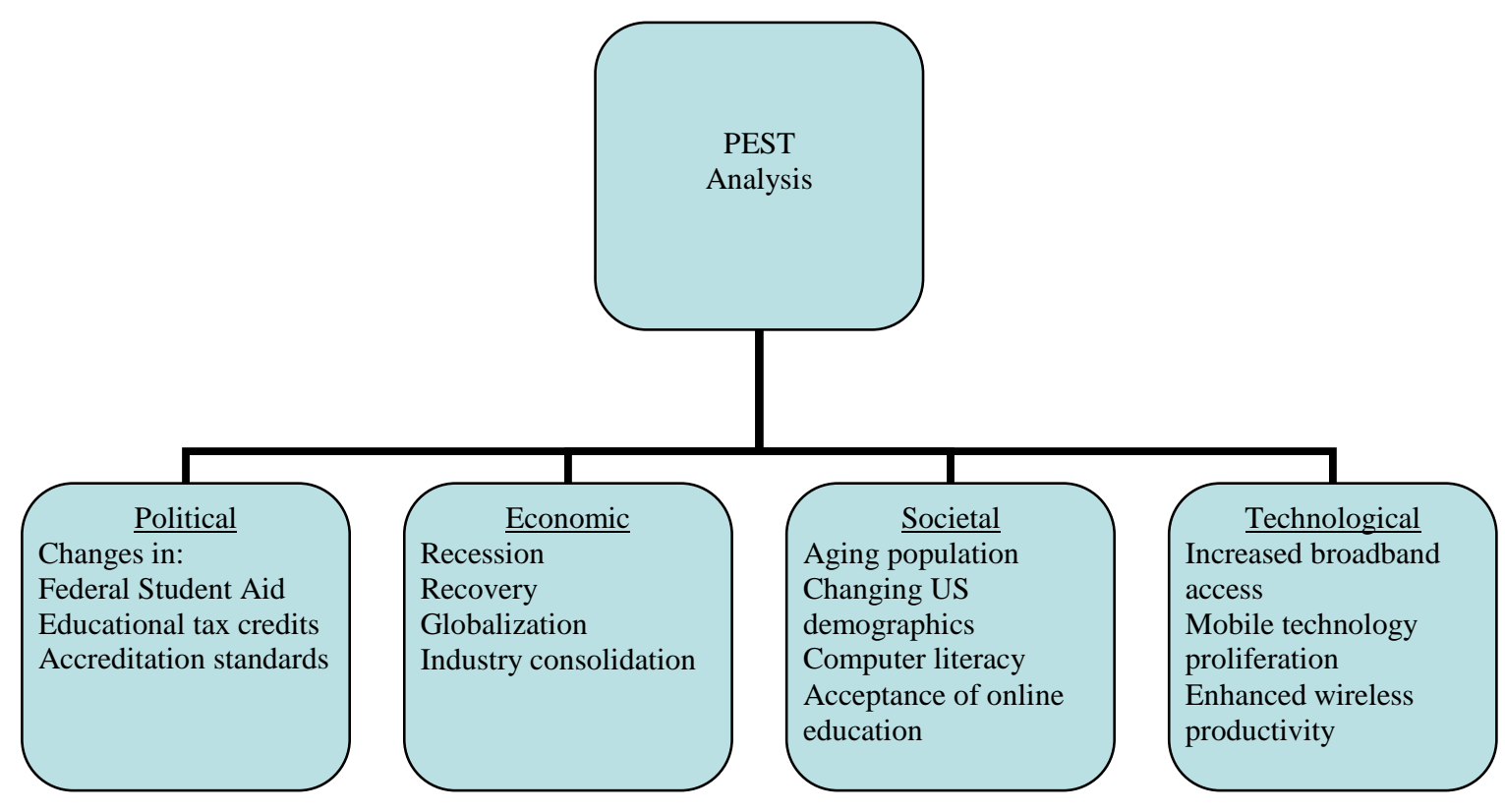

Figure 8: PEST Analysis 


\section{CONCLUSION}

Kenney College will leverage the strengths of the established operating system of the academy, while implementing innovative strategies that will enhance student professor interaction and student learning in an online environment. The key to this strategy is appreciating the fact that entrepreneurs tend to learn differently than most students and are interested in having some control in designing their learning outcomes.

Therefore, an innovative student-professor pedagogical model will be employed that strives to satisfy the student's internal locus of control and the college's desire to build a premium brand by emphasizing the humanistic, scholarly, and practical aspects of entrepreneurship.

\section{REFERENCES}

1. Antonnucci, R. V. (2001, Winter). Seven myths about online colleges: A view from inside. Retrieved January 26, 2007, from New England Journal of Higher Education Web site: http://findarticles.com/p/ articles/mi_qa3895/is_200101/ai_n8932089/print

2. Apollo Group. (2005, February 25). Retrieved February 28, 2007, from Yahoo Finance Web site: http://finance.yahoo.com/q/ks?s=APOL

3. $\quad$ Berg, G. A. (2005). Lessons from the edge. Westport, CT: Praeger.

4. Bergquist, W. H. (1992). The four cultures of the academy. San Francisco: Jossey-Bass.

5. Boyer, K. K., Tomas, G., \& Hult, M. (2005). Extending the supply chain: Integrating operations and marketing in the online grocery industry. Journal of Operations Management, 23, 642-661.

6. Career Education Corporation. (2007, February 25). Retrieved February 28, 2007, from Yahoo Finance Web site: http://finance.yahoo.com/q/ks?s=CECO

7. Clark, D. (2000, May/June 29). Learning styles. Retrieved January 25, 2007, from http://www.nwlink.com/ 〜donclark/hrd/learning/styles.html

8. Coffey, K. R., \& Millsaps, E. M. (2004). A handbook to guide educational institutions through the accreditation process. Lewiston, NY: The Edwin Mellen Press.

9. Cooper, D., Grey, S., Raymond, G., \& Walker, P. (2005). Project Risk Management Guidelines. West Sussex, England: John Wiley \& sons.

10. Dewey, J. (1916). Democracy and Education. New York: Macmillan.

11. Eisenbarth, G. (2003, September). The online education market: Much is at stake for institutions of higher education . On the Horizon, 11(3), 9-15.

12. Fisher, J. L., \& Koch, J. V. (2004). The entrepreneurial college president. Westport, CT: Praeger.

13. Franklin University Announces David Award Recipients. (2005, October 14). Retrieved January 27, 2007, from Franklin University Web site: https://www.franklin.edu/franklin/files/media-releases/05mba-facultyaward.pdf

14. Fredda, J. (2000a). Comparison of selected student outcomes for Intenet- and campus-based instruction at the Farquhar Center for Undergraduate Studies (Report 00-11). Fort Lauderdale, FL: Nova Southeastern University, Research and Planning. Retrieved October 15, 2004, from http://www.nova.edu/cwis/urp/abstracts/0011-Executive.html

15. Fredda, J. (2000b). Comparison of selected student outcomes for Internet- and campus-based instruction at the Fischler Graduate School of Education and Human Services (Report 00-16). Fort Lauderdale, FL: Nova Southeastern University, Research and Planning. Retrieved October 15, 2004, from http://www.nova.edu/cwis/urp/abstracts/0016-Executive.html

16. Fredda, J. (2000c). Comparison of selected student outcomes for Internet- and campus-based instruction at the Wayne Huizenga Graduate School of Business and Entrepreneurship (Report 00-14). Fort Lauderdale, FL: Nova Southeastern University, Research and Planning. Retrieved October 15, 2004, from: http://www.nova.edu/cwis/urp/abstracts/0014-Executive.html

17. Fredda, J. (2000d). Comparison of selected student outcomes of Internet versus campus-based instruction (Report 00-08). Fort Lauderdale, FL: Nova Southeastern University.

18. Full-Time Faculty in Higher Education. (2004, June). Back Issues in Higher education, 21(9), 117. 
19. Garrison, D. \& Anderson, T. (2003). E-learning in the $21^{\text {st }}$ Century: A framework for research and practice. New York, NY: RoutledgeFalmer.

20. Higher Learning Commission (2004). Best practices for electronically offered degree and certificate programs. Retrieved June 25, 2004, from http://www.ncacihe.org/resources/electronic_degrees/index.html.

21. Hofstrand, D. (2006, January). What is an entrepreneur? Retrieved January 25, 2007, from Iowa State University Web site: http://www.extension.iastate.edu/agdm/wholefarm/html/c5-07.html

22. Kamenetz, A. (2005, November 16). The Profit Chase. Retrieved February 25, 2007, from Slate Web site: http://www.slate.com/id/2130516/

23. Katz, Y. F., \& Yablon, Y. B. (2003). Online univesity learning: Cognitive and affective perspectives. Campus wide Information Systems, 20(2), 48-54.

24. Kenney, M. G., \& Mujtaba, B. G. (2007, April). Understanding Corporate Entrepreneurship and Development: A Practitioner View of Organizational Intrapreneurship. Jornal of Advanced Management and Entrepreneurship, $X(\mathrm{X})$.

25. Lawrence, W. (2007, February 3). Operations Management PowerPoint. Class Presentation presented at Nova Southeastern University, Ft. Lauderdale, FL.

26. Leavey Awards for Excellence In Private Enterprise Education. (2006). Retrieved January 27, 2007, from Freedoms Foundation Web site: http://www.ffvf.org/leavey.asp

27. Lechuga, V. M. (2006). The changing landscape of the academic profession: The culture of faculty at forprofit colleges and univesities. New York: Routledge.

28. Lincoln, A. (2001, February 1). Outsourcing: Talent on Tap. Retrieved January 26, 2007, from CFO Magazine Web site: http://www.cfo.com/article.cfm/3002176?f=search

29. Making the Grade: Online Education in the United States, 2006. (2007). The Sloan Consortium. Retrieved February 25, 2007, from http://www.sloan-c.org/publications/survey/index.asp

30. Matsuno, K., Metzker, J. T., \& Ozsomer, A. (2002, July). The effects of entrepreneurial proclivity and market orientation on business performance. Journal of Marketing, 66(3), 18-32.

31. McClelland, D. C. (1961). Entrepreneurial behavior and characteristics of entrepreneurs (S. Shane, Ed., pp. 499-599). The foundations of entrepreneurship: Volume 1. Northampton, MA: Edward Elgar.

(Reprinted from The achieving society)

32. Marwick, J. D. (1998, July 20). Academic outcomes assessment, a tool for student learning. UrbanaChampaign, IL: University of Illinois. (ERIC Document Reproduction Service No. ED422 991.

33. Moorhouse, D. (2001). Effect of Instructional Delivery Method on Student Achievement in a Master's of Business Administration Course at the Wayne Huizenga School of Business and Entrepreneurship (Report 01-02). Fort Lauderdale, FL: Nova Southeastern University, Research and Planning. Retrieved March 20, 2004, from: http://www.nova.edu/cwis/urp/abstracts/reports01.html

34. Moorhouse, D. \& Mujtaba, B. (2004). Effect of Instructional Delivery Method on Student Achievement in a Master's of Business Administration Course - Delivering Superior Customer Value - Offered by the Wayne Huizenga School of Business and Entrepreneurship (Report 04-03). Fort Lauderdale, FL: Nova Southeastern University, Research and Planning. Retrieved March 20, 2004, from: http://www.nova.edu/cwis/urp/abstracts/reports04.html

35. Mujtaba, B. G. and Preziosi, R. C. (2006). Adult Education in Academia: Recruiting and Retaining Extraordinary Facilitators of learning. $2^{\text {nd }}$ Edition. ISBN: 1593114753. Information Age Publishing. Greenwich, Connecticut. Phone: (203) 661-7602.

36. Mujtaba, B. \& Salghur, Shruti (May 2005). Essential of Cyberspace Education for Online Students. Journal of College Teaching and Learning, Vol. 2, Num 5.

37. Mujtaba, G. B. (June 2005a). What Do Online Students Need and Want from Their Masters of Business Administration Program. Journal of College Teaching and Learning, Vol 2, Num 6.

38. Mujtaba, B., (April 2005b). Comparing Jamaican Students' Performance with Students in the United States, the Grand Bahamas and the Online Program. The International College Teaching Methods and Styles Journal, Volume 1, Number 2.

39. Mujtaba, B., (April 2005c). Faculty Development Practices in Distance Education for Success with Culturally Diverse Students. International Business and Economics Research Journal, Volume 4, Number 4. Pages 1-13. 
40. Mujtaba, B.; Preziosi, R.; \& Mujtaba, L. (April 2004). Adult Learning, Assessment, and the Extraordinary Teacher. Journal of College Teaching and Learning. Volume 1, Number 4. Pages 29-37.

41. Pope, J. (2006, January 13). Some students prefer classes online. Boston Globe. Retrieved January 25, 2007, from http://www.boston.com/business/technology/articles/2006/01/13/ some_students_prefer_classes_online/?rss_id=Boston+Globe+--+Technology+stories

42. Postsecondary Institutions in the United States: Fall 2005 and Degrees and Other Awards Conferred: 200405. (2006, December 27). Washington, DC: National Center for Education Statistics. Retrieved January 21, 2007, from US Department of Education Web site: http://nces.ed.gov/pubsearch/ pubsinfo.asp?pubid=2007167

43. Rhode, D. L. (2006). In pursuit of knowledge. Stanford, CA: Stanford University Press.

44. Rice, E. R. (2002). New academic compact (L. A. MacMillan \& W. G. Berberet, Eds.) [Foreword]. Bolton, MA: Anker Publishing.

45. Ritzer, G. (2002). Enchanting McUniversity: Toward a spectacularly irrational university quotidian. In D. Hayes \& R. Wynyard (Eds.), The McDonaldization of Higher Education (pp. 19-32). Westport CT: Bergin \& Garvey.

46. Rudestam, K. E., \& Schoenholtz-Read, J. (2002). The coming age of adult online education. In Handbook of Online Learning (pp. 3-28). Thousand Oaks: Sage.

47. Ryan, R. (2002). Quality assurance of online courses. In R. Discenza, C. Howard, \& K. Schenk, The design and management of effective distance learning programs (pp. 155-169). Hershey, PA: Idea Group Publishing.

48. SACS. (2004). Best practices for electronically offered degree and certificate programs. Commission on Colleges. Southern Association of Colleges and Schools. Retrieved October13, 2004, from http://www.sacscoc.org/commpub1.asp

49. Schulman, A. and Sims, R. (1999). Learning in an online format versus an in-class format: An experimental study. T.H.E. (Technical Horizons in Education) Journal, 26, 54-56.

50. Shane, S. (2004). Academic Entrepreneurship: University spinoffs and wealth creation. Cheltenham, UK: Edward Elgar.

51. Sizing Up Colleges: Big vs. Small. (2007). Retrieved February 10, 2007, from College Board Web site: http://www.collegeboard.com/student/csearch/campus-life/37003.html

52. Smilor, R. (2006). Entrepreneurs and the Learning Organization. Retrieved February 25, 2007, from University of California San Diego Web site: http://beysterinstitute.org/other_resources/ article_slot_view.html_ID=675450.html

53. Stanley, T. (2000). The Millionaire Mind. Kansas City: Andrews McMeel Publishing.

54. Terenzio, M. (2002). Professional development across the faculty career: An engine for implementing a new faculty-institutional compact. In A new academic compact (pp. 29-60). Bolton, MA: Anker Publishing.

55. Verzuh, E. (1999). The fast forward MBA. New York: Wiley.

56. Whiteley, T. R. (2007, February 20). Integrating the technical resources of the online learning environment with the VAK learning styles model to foster student learning . American Marketing Association conference presentation presented at AMA Conference, San Diego, CA.

57. Zapalska, A., \& Brozik, D. (2006). Learning styles and online education . Campus Wide Information Systems, 23(5), 325-335. 